\title{
Kentsel Dönüşüm Alanlarında Kitlesel Değerleme: Elazığ ili Cumhuriyet Mahallesi Örneği
}

\author{
İrem ÖZOK YAZICI ${ }^{1}$, Faik Ahmet SESLi ${ }^{2}$ \\ ${ }^{1}$ Yozgat Kadastro Müdürlügü, Tapu ve Kadastro Genel Müdürlüğü, Yozgat. \\ ${ }^{2}$ Harita Mühendisliği Bölümü, Mühendislik Fakültesi, Ondokuz Mayıs Üniversitesi, Samsun. \\ *Sorumlu Yazar e-posta: ozokirem@gmail.com ORCID ID: http://orcid.org/0000-0003-3823-7452 \\ fasesli@omu.edu.tr ORCID ID: http://orcid.org/0000-0003-2091-032X
}

Geliş Tarihi: 07.10.2019 Kabul Tarihi: 11.02.2020

Öz

Anahtar kelimeler Elazı̆̆;

Taşınmaz Değerleme; Kitlesel Değerleme; Kentsel Dönüşüm; Ridge Regresyon.

Bu çalışma ile birden çok taşınmazın konu olduğu kentsel dönüşüm alanlarında, kitlesel değerleme yöntemi uygulanarak taşınmazların değerleri belirlenmiştir. Elâzığ ili Merkez ilçesi Cumhuriyet Mahallesi'nde bulunan 21.69 hektarlık kentsel dönüşüm alanındaki arsa ve konut vasıfı taşınmazlara Ridge regresyon analizi kullanılarak kitlesel değerleme yöntemi uygulanmıştır. Analiz sonrası elde edilen model üzerinde değişkenlerin değerleri yerine yazılarak, değer bilgisine ulaşılmıştır. Model sonrası ulaşılan değerler ile daha önce gayrimenkul şirketi tarafından belirlenen değerler karşılaştırılarak, oransal olarak farkları incelenmiştir. Çalışmada kentsel dönüşüm alanlarında taşınmazın değerinde etkili olan faktörlerin de göz önünde bulundurulduğu bir model aracılığıyla aynı anda benzer nitelikli birçok taşınmazın değerinin saptanabileceği ortaya konulmuştur. Kitlesel değerlemenin uygulanmasıyla daha az sürede ve daha az maliyetle taşınmazın değerine ulaşmanın mümkün olduğu sonucuna varılmıştır.

\section{Mass Appraisal In Urban Transformation Areas: Example Of Elazığ- Cumhuriyet Neighbourhood}

\begin{abstract}
Keywords

Elazığ;

Real Estate Valuation;

Mass Appraisal ;

Urban Transformation;

Ridge Regression.

In this study, the values of the real estates were determined by applying the mass appraisal method in the urban transformation areas where more than one real estate is the subject.Mass appraisal method was applied to land and residential real estate in 21.69 hectare urban transformation area in Cumhuriyet district of Central country of Elazig province, by using Ridge Regression analysis.After the analysis, the values of the variables were written on the model obtained and the value information was reached.The values obtained after the model were compared with the values determined by the real estate company and their proportional differences were examined.In the study, it was revealed that the value of many similar properties can be determined at the same time by means of a model in which the factors influencing the value of the real estate property are taken into consideration.With the application of the mass appraisal, it is possible to reach the value of the real estate in less time and with less cost.
\end{abstract}

(C) Afyon Kocatepe Üniversitesi

\section{Giriş}

Kentlerin yoğun göç sonrası oluşan çarpık yapılaşma, işlevini yitirme, doğal afete maruz kalma gibi olaylar sonrası çöküntüye uğramış bölgeleri bulunmaktadır. Bu bölgelerin; sosyal, kültürel, ekonomik ve fiziksel değişimlere uyum sağlaması ve kentte oluşan sorunların giderilmesi amaçlı kentsel dönüşüm faaliyetleri gerçekleştirilmektedir. Kentsel dönüşüm uygulamaları ile ekonomik ve fiziksel yönden zarara uğrayan bölgelerde, yaşam kalitesini artırmanın yanı sıra kent ekonomisini güçlendirmek de hedeflenmektedir (Köktürk ve Köktürk, 2016). Artan kentsel dönüşüm uygulama alanlarıyla birlikte 
taşınmazın değerinin belirlenmesi konusu da önemli hale gelmiştir.

Ülkemizde, afet riski altındaki alanlar ve yıpranmaya uğramış alanlar başta olmak üzere kentsel dönüşüm uygulamaları önem kazanmıştır. Mahalli ve idari birimlerinde gelecek 10 yıldaki hedefleri arasında yer aldığından, kentsel dönüşüm uygulamaları Türkiye'de hız kazanmıştır. Kentsel dönüşüm alanlarının artması, dönüşüme uğrayan alanların dönüşüm öncesi ve sonrası taşınmaz değerinin belirlenmesi konusunu öneme kavuşturmuştur.

Değerleme, ekonomik gelişmeler göz önünde bulundurularak taşınmazların niteliklerinin toplu analizi sonucunda piyasa koşullarındaki değişim değerinin kestirimidir (Açlar, 1977). Taşınmaz değerleme ise; taşınmaza ilişkin özellikler, yarar, çevre, kullanım amaçları gibi faktörlerin değerlendirilmesi amacıyla taşınmaz değerinin objektif ve tarafsız olarak belirlenmesi için yapılan işlemlerin tümüdür. Bu değer maliyet fiyatı, pazar fiyatı ya da satış fiyatı olabilmektedir (Güngör, 1997). Taşınmaz değerleme çalışmaları kapsadığı alan ya da varlık yönünden tekil değerleme ve kitlesel değerleme olarak iki başlığa ayrılabilir. Tekil değerleme, değerlemeye konu taşınmazın emsal, karşılaştırma, gelir yöntemlerinden herhangi biri uygulanarak değerinin biçilmesini amaçlamaktadır.

Vergilendirme, kamulaştırma, kentsel dönüşüm gibi nedenlerle aynı anda birden çok taşınmaza değer biçilmesi gerektiği durumlarda ise kitlesel taşınmaz değerleme yöntemi kullanılmaktadır (Tanrıvermiş, 2017). Bunun nedeni belirlenen model yardımıyla daha az maliyetle ve daha kısa sürede özellikle emlak vergilendirmesi esnasında büyük kolaylık sağlamasıdır.

Kitlesel değerleme bazı kaynaklarda küme değerleme olarak adlandırılırken bazılarında ise toplu değerleme olarak adlandırılmaktadır. Sermaye Piyasası Kurulu tarafından 6362 sayılı Kanun'a dayanılarak Seri VIII 45'nolu Tebliği ekinde yayınlanan Uluslararası Değerleme Standartlarında, kitlesel değerleme, "Sonuçların istatistiksel bir şekilde incelenmesi ve analiz edilmesine imkân sağlayan sistematik ve tek tip değerleme yöntemleri ve teknikleri kullanılarak birden fazla mülke belirli bir tarihte değerleme uygulamasıdır" şeklinde tanımlanmıştır (Anonim,2006).
Uluslararası Değerleme Çalışanları Birliği ise (IAAO) kitlesel değerlemenin tanımını, "Çok sayıdaki taşınmazın ya da taşınmazlardan oluşan grupların değerleme günündeki değerlerinin standartlaştırılmış süreçlerle ve istatistiksel testlerle belirlenmesi işlemi" şeklinde yapmaktadır (Web 1). Tekil taşınmaz değerleme belirlenen tarihte bir taşınmazın satış değerinin daha çok geleneksel yöntemler kullanılarak değerinin tespiti iken, kitlesel değerleme belirlenen tarihte birden çok taşınmazın belirlenmiş standart süreçler ve istatistiksel yöntemlerle bulunması işlemidir. Kitlesel taşınmaz değerleme, tekil taşınmaz değerlemesi ile genel olarak aynı iş akış sürecinden oluşmaktadır. Fakat kitlesel değerleme için oluşturulacak olan değerleme modelinde tek taşınmaz değerlemesinden farklı olarak, örneklem kümesinden edinilen bilgilerle değerleme kümesinin değerleme işlemi yapılmaktadır (Yılmaz, 2010).

Tekil taşınmaz değerlemesinde uzmanlar tarafından pazar analizleri kullanılarak konu taşınmazın değeri belirlenerek değerleme raporu aracılığıyla sunulmaktadır. Değerleme uzmanı hazırladığı raporda; değerlemenin hangi tarihte ve amaçla gerçekleştirildiğini, taşınmaza ilişkin hakları, kısıtlayıcı unsurları ve kestirilecek değer kavramını belirtmesi gerekmektedir. Kitlesel değerlemede ise değeri belirlenecek taşınmazlar, tanımlı alandaki tüm taşınmazlardan oluşmaktadır. Kitlesel değerlemede bulunan bölgeye ve çalışmanın amacına uygun değerleme modellerinin oluşturulması gerekir. Kitlesel değerleme işlemlerinde değerleme işleminin doğruluğu ve tutarlılığı, modelin doğru oluşturulmasına, örnek küme ve değer kümesinin özelliklerinin iyi bir şekilde analiz edilmesine ve bunların doğru bir şekilde matematiksel olarak ortaya konmasına bağlıdır. Bu nedenle kitlesel değerlemede değere etki eden değişkenlerin seçimi öneme sahiptir. Çünkü modelin matematiksel olarak gösterimi, değere etki eden değişkenlerin matematiksel modeli şeklindedir (Tokat, 2014). Tekil taşınmaz değerlemesi değerlerinin güvenilirliği ise, analizlerin ya da araştırmanın derinliğine bağlıdır. Dünyada kitlesel değerleme çalışmaları genellikle vergi değerinin tespiti, arazi toplulaştırma, kamulaştırma ve değer esaslı imar uygulamalarında kullanılmaktadır (Yıldız, 2014). 
Ülkemizde kitlesel değerleme çalışmalarının kurumsal olarak ilk uygulamasının Tapu ve Kadastro Genel Müdürlüğü tarafından, Tapu ve Kadastro Modernizasyon Projesinin 4. bileşeni olan "Gayrimenkul Değerleme Bileşeni" kapsamında gerçekleştirildiği söylenebilir. Bu uygulamada pilot alan olarak İstanbul ili Fatih ilçesi ve Ankara ili Mamak ilçesi seçilmiş olup arsaların, meskenlerin, ticari nitelikli taşınmazların kitlesel değerleme uygulamaları gerçekleştirilmiştir. Pilot Uygulama Analiz Modelleme çalışmalarında kullanılan yöntemler; Çoklu Regresyon Analizi, Yapay Sinir Ağları, Karar Ağaçları ve Lineer Modellemedir. Modelleme çalışmalarına aynı verilere farklı yöntemlerin uygulanması sonucunda ulaşılmış olup farklı yöntemlerin sonuçlarının karşılaştırılması ile daha zengin ve anlamlı sonuçların elde edilmesi sağlanmıştır (Erdem, 2017). Çalışma kapsamındaki taşınmazlar için hesaplanan değerler ile mevcut harç ve vergi değerleri arasında 2-3 kat farklılık olduğu görülmüştür. Pilot uygulamada kullanılan parametreler; brüt kapalı alan, kat numarası, metro durağına uzaklık, üniversiteye uzaklık, asansör, bina yaşı, sokak genişliği, arsa payı, rekreasyon alanlarına uzaklık, yola cephesinin olup olmadığı, brüt açık alan, parselin konumu, brüt depo alanı, balkon, süpermarkete uzaklık, metrobüs durağına uzaklık, bölgenin gelişmişlik durumu, anayola uzaklık, otobüs durağına uzaklıktır (TKGM, 2014).

$\mathrm{Bu}$ çalışmanın amacı, Elâzığ ili Merkez ilçesi Cumhuriyet Mahallesi sınırları içerisinde bulunan 21.69 hektarlık kentsel dönüşüm alanında bulunan 348 adet konutun ve 51 adet arsanın kitlesel (küme, toplu) taşınmaz değerlemesinin, Ridge regresyon analizi yöntemi kullanılarak yapılmasıdır. Yapılan çalışma ile kentsel dönüşüm alanında bulunan konutların kitlesel değerlemesi istatistiksel yöntemler yardımıyla yapılacaktır. Böylece kamulaştırma, emlak vergilendirilmesi gibi uygulamalarda daha adil sonuçlara ulaşılacaktır. Ayrıca çalışma sonrası elde edilecek model aracılı̆ı̆yla değerleme işleminin kontrolü sağlanabilecektir.

\section{Materyal ve Metot}

Elâzığ Doğu Anadolu Bölgesi'nin güneybatısında, Yukarı Fırat Bölümü'nde yer alan yaklaşık 9151 km² alana sahip olan bir ildir. Elâzığ il sahası $38^{\circ} 30^{\prime}$ ile $40^{\circ}$ $21^{\prime}$ doğu boylamları, $38^{\circ} 17^{\prime}$ ile $39^{\circ} 11^{\prime}$ kuzey enlemleri arasında kalmaktadır. Elâzığ ili topraklarının doğu-batı doğrultusundaki uzunluğu yaklaşık 150 km olup, kuzey-güney yönündeki genişliği ise yaklaşık 65 km'dir (Web 2). Çalışma alanı olan Cumhuriyet Mahallesi, Elazığ ili merkezinin 5 km kuzeybatısında yer almaktadır. Şekil 1'de Elâzığ ili Merkez ilçesine bağlı Cumhuriyet Mahallesi gösterilmektedir.

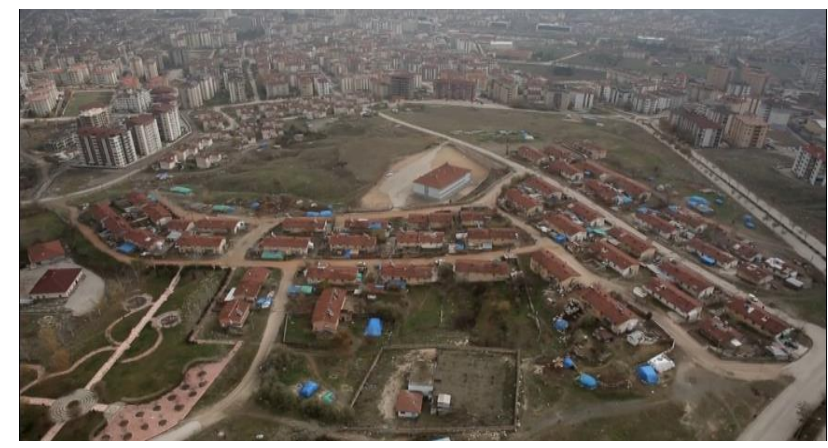

Şekil 1. Elâzığ ili Merkez ilçesi Cumhuriyet Mahallesi (Web 3)

9 Temmuz 2013 tarihli 28702 sayılı Resmi Gazete de yayınlanarak yürürlüğe giren Çevre ve Şehircilik Bakanlığı'nın 28.05.2013 tarihli ve 2649 sayılı yazısı üzerine, 6306 sayılı Afet Riski Altındaki Alanların Dönüştürülmesi

Hakkında Kanun'un 2'nci maddesine göre, Bakanlar Kurulu'nca 10.06.2013 tarihinde alanın riskli alan ilan edilmesi kararlaştırılmıştır. Cumhuriyet Mahallesi Kentsel Dönüşüm Alanı 18.84 hektar riskli alan, 2.85 hektar rezerv yapı alanı olmak üzere toplam 21.69 hektar alandan oluşmaktadır (Şekil 2).

Elâzığ ili Merkez ilçesine bağlı Cumhuriyet Mahallesi'nin gerek zemininin risk taşıması, gerekse sosyal ve ekonomik anlamda çevresinden aykırı durması kentsel dönüşüm alanı olarak belirlenmesinde etkili olmuştur.

Kentsel dönüşüm alanı içerisinde müştemilatlar hariç 138 adet yapı bulunmaktadır, bunlardan sadece biri ilköğretim tesisi olmakla birlikte geri kalanı konut kullanımlıdır. Alanda $50 \mathrm{~m}^{2}-100 \mathrm{~m}^{2}$ arasında yapılar bulunmaktadır. Yapıların çoğu yığma malzemeden oluşmaktadır. Geri kalanları ise betonarmedir. Kentsel dönüşüm alanında 3 katın üstünde mesken bulunmamaktadır.

Taşınmazın değerini etkileyen birçok faktör bulunmaktadır. Bu faktörler taşınmazın vasfına göre 
değişmektedir. Mevcut cazibe merkezlerine yakınlık, yaşanılan yerin sosyo-kültürel yapısı, şehir merkezine uzaklık, toplu taşıma araçları ile ulaşım imkânı, sosyal donatılara yakınlık ile ilgili verilerin dışında diğer tüm veriler Elâzığ Belediyesinden temin edilmiş olup bu veriler göz önünde bulundurularak taşınmazlar vasıflarına göre gruplandırılmıştır. Elâzığ ili Merkez ilçesi Cumhuriyet Mahallesi Kentsel Dönüşüm Alanı'nda 51 adet arsa vasıflı taşınmaz, 348 adet konut vasıflı taşınmaz bulunmaktadır.

Uygulama alanındaki tüm arsa ve konutlar için sosyal donatılara (anaokulu, ilkokul, ortaokul, lise, park, oyun parkı, semt parkı, devlet hastanesi, sağlık ocağı, cami, karakol, avm, şehir merkezi) olan mesafeleri ArcMap 10.3 programı yardımıyla distancematrix oluşturularak elde edilmiştir. Distancematrix, belirlenen bir nokta ile diğer noktalar arasındaki mesafenin belirlenmesini sağlayan analitik bir tekniktir. Google Earth ve Elazığ ili halihazır haritasından faydalanılarak sosyal donatıların konum bilgisine ulaşılmıştır. Kentsel dönüşüm alanında bulunan taşınmazlar ve sosyal donatılar nokta verisi olarak ArcMap ortamına aktarılmıştır. Ardından pointdistance fonksiyonu kullanılarak sosyal donatılara olan mesafe verisine ulaşılmıştır. Literatür taraması sonucunda, taşınmazın değerinin belirlenmesinde etkili olan sosyal donatılara olan mesafelerin, Mekânsal Planlar Yapım Yönetmeliği'nde belirtilen yürüme mesafeleri esas alınarak ve puanlama yapılarak elde edildiği görülmüştür. Fakat Regresyon analizinde veri tipinin nominal olmasının analiz sonuçlarına etkisi düşünülerek çalışmada tercih edilmemiştir. Bu nedenle mesafe değerlerinde Mekânsal Planlar Yapım Yönetmeliği göz önünde bulundurularak puanlama yöntemi uygulanmamıştır. Ayrıca manzara faktörünün tüm taşınmazlar için etkisi olmadığına Google Earth/Görüş Alanı fonksiyonu kullanılarak ulaşılmıştır. İlgili kentsel dönüşüm alanının sosyokültürel yapısı ile ilgili veriler oluşturulurken; Özcan (2003) "Farklı Sosyo-ekonomik ve Kültürel Grupların Etkileşimi (Elâzığ Cumhuriyet Mahallesi Örneği)" adlı yüksek lisans tez çalışması ve günümüz şartları göz önünde bulundurulmuştur.

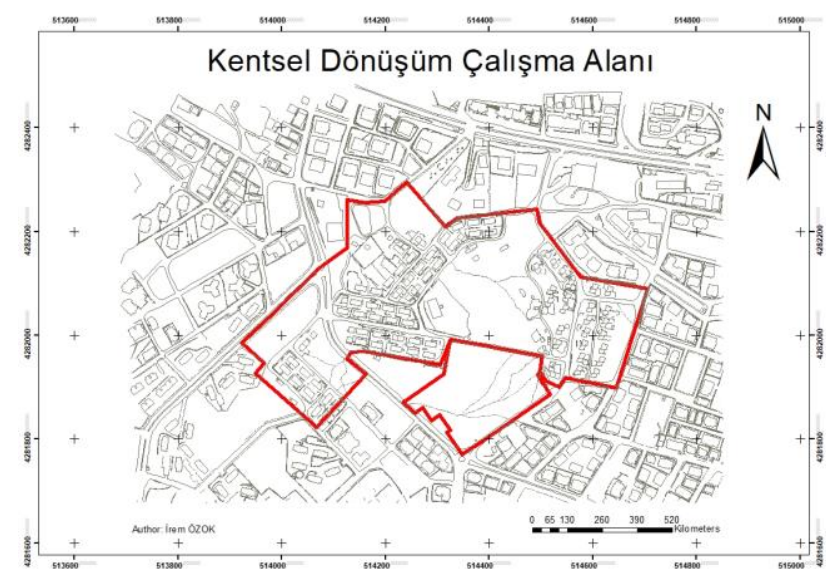

Şekil 2.Elâzığ ili Merkez ilçesi Cumhuriyet Mahallesi Kentsel Dönüşüm Çalışma Alanı Sınırı

Bu çalışmada kullanılan arsa vasıflı taşınmazın değerine etki eden faktörler Çizelge 1 'de ağırlıklarıyla birlikte gösterilmiştir.

Çizelge 1. Arsa vasıflı taşınmazın değerine etki eden faktörler (Çakır,2013)

\begin{tabular}{|c|c|c|}
\hline FAKTÖR NO & $\begin{array}{l}\text { DEĞERE ETKI EDEN } \\
\text { FAKTÖR }\end{array}$ & $\begin{array}{l}\text { FAKTÖRÜN AĞIRLIĞI } \\
\text { (AO) }\end{array}$ \\
\hline 1. & Ruhsatlı kat adedi & 82.2000 \\
\hline 2. & $\begin{array}{c}\text { Parselin imar planı } \\
\text { sonrasındaki durumu } \\
\text { (tamamının kamusal } \\
\text { alana (resmi kurum, } \\
\text { sosyo-kültürel alan, vb) } \\
\text { ya da konut kullanımı } \\
\text { dışında ki bir alana } \\
\text { (okul, yeşil alan, yol,vb) } \\
\text { denk gelmesi ) * }\end{array}$ & 77.7400 \\
\hline 3. & Parsel kullanım alanı * & 76.9000 \\
\hline 4. & $\begin{array}{l}\text { Gözde semt ya da } \\
\text { mahallede bulunup } \\
\text { bulunmaması }\end{array}$ & 75.2000 \\
\hline 5. & $\begin{array}{c}\text { Mevcut cazibe } \\
\text { merkezine yakınlık * }\end{array}$ & 72.7600 \\
\hline 6. & $\begin{array}{c}\text { İmar adası içerisindeki } \\
\text { konum * }\end{array}$ & 72.2000 \\
\hline 7. & Çevre & 71.1000 \\
\hline 8. & $\begin{array}{c}\text { Kamu hizmetlerinin } \\
\text { mevcut oluşu }\end{array}$ & 69.8000 \\
\hline 9. & $\begin{array}{c}\text { Yaşanılan yerin sosyo- } \\
\text { kültürel yapısı }\end{array}$ & 68.7400 \\
\hline 10. & Kullanılabilir alan & 68.1000 \\
\hline 11. & $\begin{array}{c}\text { Şehir merkezine olan } \\
\text { uzaklık* }\end{array}$ & 67.8600 \\
\hline 12. & $\begin{array}{c}\text { Parselin imar planı } \\
\text { sonrasındaki durumu } \\
\text { (kısmen kamusal alana } \\
\text { (resmi kurum, sosyo- } \\
\text { kültürel alan, vb) ya da } \\
\text { konut kullanımı dışında } \\
\text { ki bir alana (okul, yeşil } \\
\text { alan, yol,vb) denk } \\
\text { gelmesi) * }\end{array}$ & 67.1200 \\
\hline
\end{tabular}




\begin{tabular}{ccc}
\hline 13. & Caddeye çıkış & 66.5000 \\
\hline 14. & Manzara & 63.2400 \\
\hline 15. & Cephe* & 62.6000 \\
\hline
\end{tabular}

Alanda bulunan tüm arsalar için benzer nitelikli faktörler bulunmaktadır. Cumhuriyet Mahallesi kentin çoğunlukla tercih ettiği gelişim alanlarından biridir. Çevre faktörü, kamu hizmetlerinin mevcut oluşu, yaşanılan yerin sosyo-kültürel yapısı alandaki tüm arsalar için benzer niteliktedir. Elâzığ Belediyesi çalışanlarından elde edilen bilgi doğrultusunda alanın zemininin kayalık olduğu bilgisine ulaşıımıştır. Tüm arsalar için benzer olan değişkenler modele dâhil edilmemiştir.

Verilerin analize uygun hale getirilmesi için veri temizliği ve kontrolünün gerçekleştirilmesi gerekmektedir. Sıklık sorgulaması yapılarak, veri temizliği ve kontrolü gerçekleştirilmiştir. Bunun sonucunda, analizde yer alacak arsa vasıflı taşınmazların değerinde etkili olan faktörlere ulaşılmıştır. Çizelge 1 'de değere etki eden faktörler sütununda * simgesinin yer aldığı faktörler modelde kullanılmıştır.

Yahşi (2007), “Konut Değerlemesi ve Konut Değerlerini Etkileyen Faktörlerin Regresyon Analizi ile İncelenmesi" adlı yüksek lisans çalışmasında konut değerine etki eden faktörler çalışmada kullanılmıştır. Konut vasıfı taşınmazların değerlemesinde kullanılacak faktörler belirlenirken, belli bir alana uygun faktörler yerine daha genel faktörlerin kullanılması tercih edilmiştir. $\mathrm{Bu}$ çalışmada kullanılan konut vasıflı taşınmazların değerine etki eden faktörler ve açıklamaları Çizelge 2 'de yer almaktadır.

Çizelge 2.Konut değerini etkileyen faktörler (Yahşi,2007)

\begin{tabular}{ccc}
\hline NO & $\begin{array}{c}\text { KONUT } \\
\text { DEĞERINE ETKi } \\
\text { EDEN } \\
\text { FAKTÖRLER }\end{array}$ & AÇıKLAMA \\
\hline 1 & Cadde-Sokak* & $\begin{array}{c}\text { Konutun üzerinde konumlu olduğu } \\
\text { parselin cadde üzerinde mi yoksa } \\
\text { sokak üzerinde mi olduğunu ifade } \\
\text { etmektedir. }\end{array}$ \\
\hline 2 & Arsa Alanı* & Konutun konumlu olduğu arsanın \\
yüzölçümüdür.
\end{tabular}

\begin{tabular}{|c|c|c|}
\hline 7 & $\begin{array}{l}\text { Toplu Taşıma } \\
\text { Araçları İle } \\
\text { Ulaşım İmkânı* }\end{array}$ & $\begin{array}{c}\text { Konutun toplu taşıma araçları ile } \\
\text { ulaşım imkânlarının var olup olmadığı } \\
\text { bilgisini verir. }\end{array}$ \\
\hline 8 & $\begin{array}{l}\text { Sosyal } \\
\text { Donatılara } \\
\text { Yakınlık* }\end{array}$ & $\begin{array}{l}\text { Konutun sosyal donatılara olan } \\
\text { mesafesini ifade etmektedir. }\end{array}$ \\
\hline 9 & $\begin{array}{l}\text { Bölgenin Hitap } \\
\text { Ettiği Gelir } \\
\text { Grubu }\end{array}$ & $\begin{array}{l}\text { Konutun bulunduğu bölgenin hangi } \\
\text { gelir grubu tarafından tercih edildiğini } \\
\text { göstermektedir. }\end{array}$ \\
\hline 10 & Yapı Cinsi* & Betonarme, Ahşap, Kârgir vs. \\
\hline 11 & Yapı Nizamı & $\begin{array}{l}\text { Konutun bulunduğu ana } \\
\text { gayrimenkulün bitişik nizam veya } \\
\text { ayrık nizamda olup olmadığını } \\
\text { anlatmaktadır. }\end{array}$ \\
\hline 12 & $\begin{array}{l}\text { Gayrimenkul } \\
\text { Türü }\end{array}$ & $\begin{array}{c}\text { Konutun apartman dairesi veya } \\
\text { müstakil daire olup olmadığını } \\
\text { anlatmaktadır. }\end{array}$ \\
\hline 13 & İnşaat Seviyesi & $\begin{array}{c}\text { Konutun mevcut inşaat seviyesinin } \\
\text { tamamlanıp tamamlanmadığı ifade } \\
\text { etmektedir. }\end{array}$ \\
\hline 14 & $\begin{array}{l}\text { Kullanım } \\
\text { Durumu }\end{array}$ & $\begin{array}{l}\text { Incelenen konutun mevcutta kiracı } \\
\text { veya mal sahibi tarafından } \\
\text { kullanılması ile boş olmasını ifade } \\
\text { etmektedir. }\end{array}$ \\
\hline 15 & İşçilik Kalitesi & $\begin{array}{l}\text { Konutun dekorasyon özelliklerinde } \\
\text { iş̧̧ilik kalitesini ifade etmektedir. }\end{array}$ \\
\hline 16 & Malzeme Kalitesi & $\begin{array}{l}\text { Konutun dekorasyon özelliklerinde } \\
\text { malzeme kalitesini ifade etmektedir. }\end{array}$ \\
\hline 17 & Binanın Yaşı & $\begin{array}{c}\text { Konutun bulunduğu ana } \\
\text { gayrimenkulün yaşıdır. }\end{array}$ \\
\hline 18 & Deprem Bölgesi & $\begin{array}{l}\text { Konutun bulunduğu bölgenin hangi } \\
\text { derecedeki deprem bölgesinde } \\
\text { bulunduğunu ifade etmektedir. }\end{array}$ \\
\hline 19 & Deprem Hasarı & $\begin{array}{l}\text { Konutun bulunduğu ana } \\
\text { gayrimenkulde deprem hasarlı olup } \\
\text { olmadığını ifade etmektedir. }\end{array}$ \\
\hline 20 & $\begin{array}{l}\text { Yeni Deprem } \\
\text { Yönetmeliklerine } \\
\text { Uygun Olup } \\
\text { Olmadığı }\end{array}$ & $\begin{array}{l}\text { Konutun bulunduğu ana } \\
\text { gayrimenkulün yeni deprem } \\
\text { yönetmeliklerine uygun olup } \\
\text { olmadığını ifade etmektedir. }\end{array}$ \\
\hline 21 & $\begin{array}{l}\text { Tasdikli } \\
\text { Projesine Uygun } \\
\text { Olup Olmadığı }\end{array}$ & $\begin{array}{l}\text { Konutun bulunduğu ana } \\
\text { gayrimenkulün ve konutun mimari, } \\
\text { kat, kattaki konum, kapalı alan olarak } \\
\text { uygun olup olmadığını anlatmaktadır. }\end{array}$ \\
\hline 22 & Elektrik & $\begin{array}{c}\text { Konutun şebeke elektriğinden } \\
\text { yararlanıp yararlanmadığını ifade } \\
\text { etmektedir. }\end{array}$ \\
\hline 23 & Su & $\begin{array}{l}\text { Konutun şebeke suyundan yararlanıp } \\
\text { yararlanmadığını ifade etmektedir. }\end{array}$ \\
\hline 24 & Yakıt & $\begin{array}{c}\text { Konutta kullanılan yakıt türünü } \\
\text { (doğalgaz, katı yakıt vb.) ifade } \\
\text { etmektedir. }\end{array}$ \\
\hline 25 & Isıtma Sistemi & $\begin{array}{l}\text { Konutta bulunan ısıtma sistemini } \\
\text { (doğalgaz, soba vb.) anlatmaktadır. }\end{array}$ \\
\hline 26 & Hidrofor & $\begin{array}{l}\text { Konutun bulunduğu ana } \\
\text { gayrimenkulde hidrofor ve su deposu } \\
\text { bulunup bulunmadığını } \\
\text { anlatmaktadır. }\end{array}$ \\
\hline 27 & Asansör & $\begin{array}{l}\text { Konutun bulunduğu ana } \\
\text { gayrimenkulde asansör olup } \\
\text { olmadığını ifade etmektedir. }\end{array}$ \\
\hline 28 & $\begin{array}{c}\text { Ana } \\
\text { Gayrimenkulün } \\
\text { Kat Adedi }\end{array}$ & $\begin{array}{l}\text { Konutun bulunduğu ana } \\
\text { gayrimenkulün kaç katlı olduğunu } \\
\text { ifade etmektedir. }\end{array}$ \\
\hline 29 & $\begin{array}{l}\text { Toplam Bağımsız } \\
\text { Bölüm Adedi }\end{array}$ & $\begin{array}{l}\text { Konutun bulunduğu ana } \\
\text { gayrimenkulde bulunan bağımsız } \\
\text { bölüm sayısını ifade etmektedir. }\end{array}$ \\
\hline 30 & Katı* & $\begin{array}{c}\text { Konutun bulunduğu katı ifade } \\
\text { etmektedir. }\end{array}$ \\
\hline 31 & Oda Sayısı* & $\begin{array}{l}\text { Konutun salon dâhil oda ifade } \\
\text { etmektedir. }\end{array}$ \\
\hline
\end{tabular}




\begin{tabular}{|c|c|c|}
\hline 32 & Balkon Sayısı & $\begin{array}{l}\text { Konutta bulunan balkon sayısını ifade } \\
\text { etmektedir. }\end{array}$ \\
\hline 33 & Cephe Sayısı* & $\begin{array}{l}\text { Konutun binada kaç cephesi olduğunu } \\
\text { anlatmaktadır. }\end{array}$ \\
\hline 35 & Site & $\begin{array}{l}\text { Konutun site içinde yer alıp almadığını } \\
\text { ifade etmektedir. }\end{array}$ \\
\hline 36 & Otopark & $\begin{array}{l}\text { Konuta ait otopark mevcut olup } \\
\text { olmadığını ifade etmektedir. }\end{array}$ \\
\hline 37 & Şömine & $\begin{array}{c}\text { Konutta şömine bulunup } \\
\text { bulunmadığını ifade etmektedir. }\end{array}$ \\
\hline 38 & Jakuzi & $\begin{array}{l}\text { Konutta jakuzi bulunup bulunmadığını } \\
\text { ifade etmektedir. }\end{array}$ \\
\hline 39 & Yüzme Havuzu & $\begin{array}{c}\text { Konutun yüzme havuzuna sahip olup } \\
\text { olmadığını ifade etmektedir. }\end{array}$ \\
\hline 40 & Güvenlik & $\begin{array}{l}\text { Konutun güvenlik sistemine sahip } \\
\text { olup olmadığını anlatmaktadır. }\end{array}$ \\
\hline 41 & $\begin{array}{c}\text { Konutun Brüt } \\
\text { Kullanım Alanı } \\
\left(\mathrm{m}^{2}\right)^{*}\end{array}$ & $\begin{array}{c}\text { Konutun brüt kullanım alanını ifade } \\
\text { etmektedir. }\end{array}$ \\
\hline 42 & $\begin{array}{l}\text { Değerleme } \\
\text { Tarihi }\end{array}$ & $\begin{array}{l}\text { Değerleme raporlarının düzenlendiği } \\
\text { tarihi ifade etmektedir. }\end{array}$ \\
\hline 43 & Değer & Konutun değeri ifade etmektedir. \\
\hline
\end{tabular}

Çizelge 2'de bulunan takyidat durumu, kullanım durumu, deprem hasarı ile ilgili verilere yetkili kurumlardan temin edilemediğinden çalışmada bu veriler kullanılamamıştır. Kentsel dönüşüm alanları için zeminin risk taşıması durumu önemli bir husustur fakat Elazığ Belediyesi'nden elde edilen verilerde zemin risk durumu tüm taşınmazlar için benzer tanımlandığından çalışmada kullanılamamıştır. Çalışma alanındaki tüm konutlar için benzer olan faktörler bulunmaktadır. Kentsel dönüşüm alanında ikamet eden vatandaşların gelir düzeyi düşüktür. Alandaki tüm yapıların yapı nizamı ayrık olup inşaatı tamamlanmıştır. Elazığ Belediyesi'nden temin edilen belgeler doğrultusunda; 1980 yılında devlet eliyle yapılan konutlar olduğu, işçilik kalitesi ve malzeme kalitesinin tüm taşınmazlar için benzer olduğu, binaların yaş faktörünün aynı olduğu sonuçları çıkarılmıştır. Cumhuriyet Mahallesi'nde bulunan kentsel dönüşüm alanı 2. deprem kuşağında yer almaktadır. Elâzığ Belediyesi'nden edinilen bilgiler doğrultusunda çalışma alanındaki konutlar tasdikli projesine ve yeni deprem yönetmeliğine uygun değildir. Alandaki konutlar elektrik ve su tesisatına sahiptir. Çalışma alanında barınan vatandaşlar soba ile ısınmakta ve katı yakıt kullanmaktadırlar. Konutlar site içinde yer almamaktadır. Otopark, şömine, jakuzi, yüzme havuzu ve güvenliği bulunmamaktadır. Alandaki hiçbir konutta hidrofor ve asansör kullanılmamaktadır. Gayrimenkul değerleme firması tarafından yapılan değerleme tarihi tüm taşınmazlar için 2014'tür. Sağlıklı bir analiz gerçekleştirilebilmesi için veri temizliği yapılmıştır. Bunun sonucunda tüm konutlar için benzer olan faktörler modele dâhil edilmemiştir. Veri temizliği sonrası analizde kullanılacak veriler Çizelge $2^{\prime}$ de ${ }^{*}$ simgesiyle belirtilmiştir.

Yapılan literatür taraması sonucunda birçok ülkede Çoklu Regresyon analizi kullanılarak kitlesel değerleme yönteminin uygulandığı görülmüştür. Bu nedenle çalışmada Çoklu Regresyon analizinin uygulanması hedeflenmiştir. Fakat Çoklu Regresyon analizinin uygulanabilmesi için değişkenler arasında çoklu doğrusal bağlantının olmaması gerekmektedir. Ridge regresyon; çoklu doğrusal bağlantı probleminin giderilmesi için En Küçük Kareler yöntemine alternatif olarak önerilen bir regresyon yöntemidir(Akçay ve Sarıözkan,2015).

Hoerl ve Kennard (1970), bağımsız değişkenler arasında çoklu bağlantı sorununun giderilmesi, En Küçük Kareler yönteminden daha küçük varyanslı değişkenler elde edebilmek için Ridge regresyon yöntemini önermişlerdir.

Yüksek korelasyon, değişkenler arasında çoklu bağlantı sorununun olabileceğini göstermektedir. Çoklu bağlantı sorununun varlığı değişkenler arasındaki yüksek korelasyonun dışında, VIF değeri ve koşul sayısı gibi değerlerin de incelenmesiyle kesinlik kazanmıştır. Çalışmada kullanılacak değişkenler arasında yüksek korelasyon bulunması ve VIF değerinin incelenmesi sonucunda çoklu doğrusal bağlantı sorunun olduğu görülmüştür. Çoklu doğrusal bağlantı bulunması nedeniyle daha anlamlı bir model elde edebilmek amacıyla Ridge regresyon analizi tercih edilmiştir. Yöntemin kullanım şekli ve işleyişi aşağıda anlatılmıştır.

Ridge regresyon ve En Küçük Kareler (EKK) yönteminin işleyişi arasındaki tek fark, Ridge regresyonda varyans ve kovaryans matrisinin köşegen değerlerine yanlılık sabiti Ridge parametresinin (k) ilave edilmesidir. Ridge parametresinin ( $\mathrm{k}$ ) ilave edilmesi ile hata kareler ortalamasının değerinin azaldığı görülmektedir. Uygun $k$ değerinin seçiminde varyans şişirme değerinin 10'dan küçük olduğu durumlar göz önünde bulundurulur (Marquardt and Snee, 1975).

EKK yönteminde değişkenler arasında güçlü ilişkiler söz konusu olduğunda varyanslar büyümekte, bu 
nedenle tahminler gerçek değerinden uzaklaşmaktadır. Bu durumu gidermek amacıyla yanlı tahmin tekniği olan Ridge regresyon analizi geliştirilmiştir. Doğrusallık, eşvaryans ve bağımsızlık varsayımları her iki yöntem için de aynıdır. Fakat yanlı tahmin tekniklerinde güven aralığı hesaplanmadığı için yanlı tahminlerde normallik varsayımı aranmaz. Bağımsız değişkenler arasında güçlü ilişkinin olduğu durumlarda daha güvenilir değerler elde edebilmek için yanlı tahmin teknikleri tercih edilmektedir. Çok büyük örneklerle gerçekleştirilen Ridge regresyon analizi ile durağan ve güvenilir tahmin doğrularına ulaşmak mümkündür (Maxwell,2000).

\section{Bulgular}

Elâzığ ili Merkez ilçesi Cumhuriyet Mahallesi sınırları içerisinde yer alan kentsel dönüşüm alanında bulunan taşınmazlar, arsa vasıflı ve konut vasıflı olarak iki gruba ayrılmıştır. Bu nedenle arsa vasıflı taşınmazların analizi gerçekleştirildikten sonra konut vasıflı taşınmazların analizi gerçekleştirilmiştir. Analizlerin gerçekleştirilmesinde NCSS 12 istatistik paket programının deneme sürümü kullanılmıştır.

\subsection{Arsa Vasıflı Taşınmazlara Ait Analiz Sonuçları}

$\mathrm{Bu}$ çalışmada arsa değeri bağımlı değişken olarak kullanılmıştır. Parselin imar planı sonrası durumu, parsel kullanım alanı, sosyal donatılara (anaokulu, ilkokul, ortaokul, lise, oyun parkı, semt parkı, park, devlet hastanesi, sağlık ocağı, cami, karakol, şehir merkezi, otobüs durağı ve avm) olan mesafeler, imar adası içindeki konumu, cephe sayısı faktörleri ise bağımsız değişken olarak kullanılmıştır. Parselin imar planı sonrası durumu (ImarPSonra), İmar adası içerisindeki konumu (AdaiciKonum), Caddeye çıkış (CaddeyeCikis) olarak kısaltılarak analizlerde kullanılmıştır.

Uygulandığında çoklu bağlantı problemini ortadan kaldıran ve en büyük belirtme katsayısı $\left(R^{2}\right)$ değerini veren katsayının ridge parametresi $(k)$ değerinin belirlenmesine yönelik Ridge regresyon analiz sonucu Çizelge 3'te verilmiştir. k değerinin 0 olması durumunda en küçük kareler (EKK) yöntemi için katsayı tahminleri elde edilmektedir. Çizelge 3'e göre $\mathrm{k}=0$ için $\mathrm{R}^{2}$ belirtme katsayısı \%90.7 olmasına rağmen, maksimum VIF (Variance Inflation Factors=
Varyans Şişirme Faktör) değerinin 10'un üzerinde olması (27847853.40) çoklu bağlantının varlığını göstermektedir. Fakat k=0.03 Ridge parametresinde $\mathrm{R}^{2}=\% 71.56^{\prime}$ ya düşse de, VIF değeri 10'un altında olduğundan daha güvenilir sonuçlar elde etmek mümkündür. Bu nedenle $k$ değeri 0.03 olarak belirlenmiştir.

Çizelge 3.Arsa modeli için $\mathrm{k}$ parametresi seçimi

\begin{tabular}{|c|c|c|c|c|c|}
\hline $\mathbf{k}$ & $\mathbf{R}^{2}$ & Sigma & B'B & Ave VIF & Max VIF \\
\hline \multirow[t]{2}{*}{0.0000} & 0.9070 & 418321.7 & 12339 & 2936360. & 2784785 \\
\hline & & 743 & 50.06 & 83 & 3.40 \\
\hline \multirow[t]{2}{*}{0.0010} & 0.7817 & 640886.6 & 22.34 & 71.27 & 189.62 \\
\hline & & 766 & & & \\
\hline \multirow[t]{2}{*}{0.0020} & 0.7669 & 662350.7 & 10.16 & 37.62 & 101.07 \\
\hline & & 265 & & & \\
\hline \multirow[t]{2}{*}{0.0030} & 0.7589 & 673512.7 & 6.25 & 24.85 & 63.42 \\
\hline & & 398 & & & \\
\hline \multirow[t]{2}{*}{0.0040} & 0.7537 & 680805.5 & 4.44 & 18.24 & 43.75 \\
\hline & & 488 & & & \\
\hline \multirow[t]{2}{*}{0.0050} & 0.7498 & 686160.1 & 3.43 & 14.25 & 32.13 \\
\hline & & 661 & & & \\
\hline \multirow[t]{2}{*}{0.0060} & 0.7467 & 690386.2 & 2.80 & 11.60 & 27.56 \\
\hline & & 393 & & & \\
\hline \multirow[t]{2}{*}{0.0070} & 0.7441 & 693889.6 & 2.38 & 9.73 & 24.14 \\
\hline & & 279 & & & \\
\hline \multirow[t]{2}{*}{0.0080} & 0.7419 & 696898.4 & 2.08 & 8.35 & 21.40 \\
\hline & & 942 & & & \\
\hline \multirow[t]{2}{*}{0.0090} & 0.7399 & 699551.8 & 1.87 & 7.29 & 19.16 \\
\hline & & 893 & & & \\
\hline \multirow[t]{2}{*}{0.0100} & 0.7382 & 701939.8 & 1.70 & 6.46 & 17.29 \\
\hline & & 201 & & & \\
\hline \multirow[t]{2}{*}{0.0200} & 0.7252 & 719054.7 & 1.06 & 2.93 & 8.36 \\
\hline & & 333 & & & \\
\hline \multirow[t]{2}{*}{0.0300} & 0.7156 & 731541.6 & 0.89 & 1.89 & 5.43 \\
\hline & & 949 & & & \\
\hline \multirow[t]{2}{*}{0.0400} & 0.7072 & 742319.3 & 0.81 & 1.40 & 3.90 \\
\hline & & 653 & & & \\
\hline \multirow[t]{2}{*}{0.0500} & 0.6994 & 752120.4 & 0.75 & 1.12 & 2.98 \\
\hline & & 751 & & & \\
\hline \multirow[t]{2}{*}{0.0600} & 0.6921 & 761239.6 & 0.71 & 0.94 & 2.36 \\
\hline & & 595 & & & \\
\hline \multirow[t]{2}{*}{0.0700} & 0.6851 & 769829.3 & 0.68 & 0.81 & 2.01 \\
\hline & & 375 & & & \\
\hline \multirow[t]{2}{*}{0.0800} & 0.6784 & 777981.9 & 0.66 & 0.71 & 1.83 \\
\hline & & 203 & & & \\
\hline 0.0900 & 0.6719 & 785759.7 & 0.64 & 0.64 & 1.68 \\
\hline & & 514 & & & \\
\hline 0.1000 & 0.6657 & 793208.1 & 0.62 & 0.58 & 1.55 \\
\hline & & 442 & & & \\
\hline 0.2000 & 0.6116 & 854873.6 & 0.48 & 0.31 & 0.89 \\
\hline & & 987 & & & \\
\hline 0.3000 & 0.5681 & 901480.7 & 0.40 & 0.22 & 0.68 \\
\hline & & 990 & & & \\
\hline 0.4000 & 0.5317 & 938781.3 & 0.34 & 0.17 & 0.54 \\
\hline & & 321 & & & \\
\hline 0.5000 & 0.5004 & 969634.1 & 0.29 & 0.14 & 0.45 \\
\hline & & 938 & & & \\
\hline 0.6000 & 0.4731 & 995741.2 & 0.26 & 0.12 & 0.38 \\
\hline & & 341 & & & \\
\hline 0.7000 & 0.4491 & 1018212. & 0.23 & 0.10 & 0.34 \\
\hline & & 9260 & & & \\
\hline 0.8000 & 0.4276 & 1037817. & 0.20 & 0.09 & 0.30 \\
\hline & & 7745 & & & \\
\hline 0.9000 & 0.4084 & $\begin{array}{c}1055110 . \\
4580\end{array}$ & 0.18 & 0.08 & 0.27 \\
\hline
\end{tabular}




\begin{tabular}{cccccc}
1.0000 & 0.3910 & $\begin{array}{c}1070504 . \\
3517\end{array}$ & 0.17 & 0.07 & 0.24 \\
\hline
\end{tabular}

Ridge parametresi olarak seçilen $\mathrm{k}=0.03$ değeri için elde edilen Ridge regresyon analizi sonuçları Çizelge 4 'te sunulmuştur. Ridge regresyon analizi sonucunda VIF değerlerinin 10'dan küçük olduğu görülmektedir. k=0.02 olarak seçilebilirdi ancak VIF değerinin 10'a çok yakın olması güvenirliliği etkileyeceğinden $k=0.03$ olarak seçildi. Çizelge 4 'te bulunan $t$ değerleri göz önünde bulundurulduğunda modeli en çok etkileyen faktörün parselin imar planı sonrası durumu olduğu görülmektedir.

Çizelge 4.Arsa modeli Ridge regresyon analiz sonuçları $(k=0.03)$

\begin{tabular}{|c|c|c|c|c|c|}
\hline $\begin{array}{c}\text { Bağımsız } \\
\text { Değişkenler }\end{array}$ & $\begin{array}{c}\text { Regresy } \\
\text { on } \\
\text { Katsayı } \\
\text { sı }\end{array}$ & $\begin{array}{c}\text { Standar } \\
\text { laştırılm } \\
\text { Regresy } \\
\text { n } \\
\text { Katsayı }\end{array}$ & & VIF & $\begin{array}{c}\mathbf{t} \\
\text { değeri }\end{array}$ \\
\hline Intercept & -9881979 & & & & \\
\hline ImarPSonra & 297302.3000 & 195623.1 & 0.18 & 1.6 & 1.519771 \\
\hline K_alan & 6896.2510 & 854.4999 & 0.8 & 1.1 & 8.070511 \\
\hline Anaokul & -304.7380 & 2112.16 & -0.02 & 1.91 & -0.14428 \\
\hline Ilkokul & -2697.820 & 1540.846 & -0.13 & 0.59 & -1.75087 \\
\hline Ortaokul & 1185.8380 & 953.7853 & 0.08 & 0.43 & 1.243297 \\
\hline Lise & 1132.6330 & 2740.093 & 0.05 & 1.96 & 0.413356 \\
\hline OyunPark & 717.24910 & 10560.3 & 0.01 & 1.65 & 0.067919 \\
\hline SemtPark & 670.20870 & 544.2491 & 0.11 & 0.82 & 1.231437 \\
\hline Park & -1213.1500 & 885.2327 & -0.12 & 0.92 & -1.37043 \\
\hline Dhastane & 641.2440 & 515.8746 & 0.1 & 0.74 & 1.243023 \\
\hline SagOcak & 399.0945 & 906.9112 & 0.02 & 0.27 & 0.440059 \\
\hline Cami & 4518.4800 & 4026.612 & 0.14 & 1.71 & 1.122154 \\
\hline Karakol & 530.9416 & 2374.522 & 0.02 & 0.7 & 0.223599 \\
\hline Smerkez & -1.5631 & 1359.204 & 0 & 5.04 & -0.00115 \\
\hline $\begin{array}{l}\text { OtobusDur } \\
\text { ak }\end{array}$ & -2919.3300 & 3503.68 & -0.14 & 3.04 & -0.83322 \\
\hline Avm & -1329.9200 & 1554.96 & -0.19 & 5.43 & -0.85528 \\
\hline $\begin{array}{l}\text { AdaiciKonu } \\
\mathrm{m}\end{array}$ & 261723.5000 & 361551.5 & 0.12 & 2.97 & 0.72389 \\
\hline Cephe & -405103.3000 & 259656.2 & -0.26 & 3.12 & -1.56015 \\
\hline
\end{tabular}

Regresyon katsayılarının kullanılması sonucu oluşan regresyon denklemi aşağıdaki gibidir:

Değer $=-9881979+297302.3000 *$ ImarPSonrat 6896.2510*K_alan-304.7378*Anaokul-

2697.8230*Ilkokul+1185.8380*Ortaokul+

\subsection{0*Lise+717.2491*OyunPark+} 670.2087*SemtPark-1213.1460*Park+ 641.2440*Dhastane+399.0945*SagOcak+ $4518.4800^{*}$ Cami+530.9416*Karakol-

1.56314*Smerkez-2919.3260*OtobusDurak$1329.9230 *$ Avm $+261723.5000 *$ AdaiciKonum405103.3000*Cephe

Anaokuluna, ilkokula, şehir merkezine, otobüs durağına AVM'ye olan mesafeler ve cephe sayısı değişkenlerinin modeli negatif yönlü etkilediği görülmektedir. Parselin imar planı sonrası durumu, parselin imar adası içindeki konumu, parselin kullanılabilir alanı, ortaokuluna, liseye, oyun parkına, semt parkına, parka, devlet hastanesine, sağlık ocağına, camiye, karakola olan mesafe değişkenlerinin ise modeli pozitif yönde etkilediği görülmektedir.

Kentsel dönüşüm alanında bulunan rastgele seçilen 5 adet arsa vasıflı taşınmazın değeri, Çizelge 5 'te yer alan değerlerin formülde yerine yazılması sonucunda elde edilmiştir.

Çizelge 5.Arsa modelinde yer alan değişkenlerin sayısal değerleri ve değer sonucu

\begin{tabular}{llllll}
\hline & Arsa 1 & Arsa 2 & Arsa 3 & Arsa 4 & Arsa 5 \\
\hline ImarPSonra & 1 & 2 & 1 & 1 & 1 \\
\hline K_alan & 116.67 & 521.11 & 723.33 & 126.25 & 92.5 \\
\hline Anaokul & 1555.547 & 1453.764 & 1415.3727 & 1385.7994 & 1393.6169 \\
\hline Ilkokul & 1060.8464 & 999.86376 & 1001.2449 & 1007.2255 & 1008.1446 \\
\hline Ortaokul & 1901.5632 & 1796.1669 & 1755.8241 & 1732.7334 & 1717.4118 \\
\hline Lise & 2043.9838 & 2051.655 & 2056.3827 & 2065.8958 & 2069.4334 \\
\hline OyunPark & 1687.6952 & 1674.169 & 1682.531 & 1689.4225 & 1694.5885 \\
\hline SemtPark & 3019.269 & 2771.6978 & 2689.1927 & 2635.6093 & 2605.3113 \\
\hline Park & 567.34875 & 381.23161 & 333.59912 & 308.53306 & 294.00796 \\
\hline Dhastane & 5965.1483 & 5716.2474 & 5632.3821 & 5578.0592 & 5546.9788 \\
\hline SagOcak & 1326.8368 & 1234.3101 & 1206.4348 & 1191.9853 & 1182.4266 \\
\hline Cami & 750.34689 & 704.69699 & 694.90628 & 692.01726 & 689.18952 \\
\hline Karakol & 2239.6653 & 2201.2869 & 2182.5144 & 2174.0231 & 2166.7999 \\
\hline Smerkez & 5298.2123 & 5046.3498 & 4958.9386 & 4903.1002 & 4870.2859 \\
\hline OtobusDurak & 399.92894 & 334.49614 & 332.95195 & 333.6321 & 338.37136 \\
\hline Avm & 1416.6563 & 1187.8499 & 1104.7494 & 1054.2117 & 1022.7602 \\
\hline AdaiciKonum & 1 & 1 & 0 & 1 & 0 \\
\hline Cephe & 2 & 2 & 1 & 2 & 1 \\
\hline Değer(Model) & 325.569 & 361.392 & 4.824 .591 & 546.458 & 426.772 \\
\hline & & & & &
\end{tabular}

Model aracılığıyla ulaşılan taşınmaz değeri ile gayrimenkul değerleme şirketi tarafından takdir edilen taşınmaz değeri de Çizelge 6'da yer almaktadır. Tüm arsa vasıflı taşınmazlar dikkate alındığında model sonucu oluşan değer ile 
gayrimenkul şirketi tarafından belirlenen değer arasındaki fark minimum \%11.41, maksimum \%36.35 olarak bulunmuştur.

Çizelge 6.Arsa modeli sonucu elde edilen değer ile gayrimenkul şirketi tarafından belirlenen değer karşılaştırması

\begin{tabular}{lccccc}
\hline & Arsa 1 & Arsa 2 & Arsa 3 & Arsa 4 & Arsa 5 \\
\hline $\begin{array}{l}\text { Değer(Model) } \\
\text { (TL) }\end{array}$ & 325.56 & 361.39 & 4824.5 & 546.45 & 426.77 \\
\hline $\begin{array}{l}\text { Değer(Değerlem } \\
\text { e Şirketi) (TL) }\end{array}$ & 367.50 & 502.50 & 6975.0 & 858.50 & 629.00 \\
\hline Fark(\%) & 11.41 & 28.08 & 30.83 & 36.35 & 32.15 \\
\hline
\end{tabular}

\subsection{Konut Vasıfı Taşınmazlara Ait Analiz Sonuçları}

Konut değeri bağımlı değişken olarak kullanılmıştır. Cadde-sokak, arsa alanı, mülkiyet durumu, yapı cinsi, bulunduğu kat, oda sayısı, cephe sayısı, konutun brüt kullanım alanı, sosyal donatılara uzaklığı faktörleri ise bağımsız değişkenlerdir. Cadde-Sokak (CadSok), Mülkiyet Durumu (MulkiyetD), Yapı Cinsi (YapiCins), Arsa alanı (Alan), bulunduğu kat (Bkatı), Oda sayısı (Odasayı) olarak kısaltılarak analizlerde kullanılmıştır.

Uygulandığında çoklu bağlantı problemini ortadan kaldıran ve en büyük belirtme katsayısı $\left(R^{2}\right)$ değerini veren katsayının ridge parametresi (k) değerinin belirlenmesine yönelik Ridge regresyon analiz sonucu Çizelge 7'de verilmiştir.

Çizelge 7.Konut modeli için k parametresi seçimi

\begin{tabular}{cccclll}
\hline $\mathbf{k}$ & $\mathbf{R}^{\mathbf{2}}$ & Sigma & $\mathbf{B}$ 'B & Ave VIF & \multicolumn{1}{c}{ Max VIF } \\
\hline 0.000 & 0.874 & 41839.126 & 8155.1 & $\begin{array}{l}6563293 . \\
92\end{array}$ & \\
\hline 0.001 & 0.869 & 42816.380 & 3.51 & 43.03 & 167.48 \\
\hline 0.002 & 0.865 & 43361.766 & 3.27 & 24.14 & 82.48 \\
\hline 0.003 & 0.862 & 43871.920 & 3.13 & 16.98 & 50.48 \\
\hline 0.004 & 0.859 & 44356.737 & 3.01 & 13.19 & 34.53 \\
\hline 0.005 & 0.856 & 44820.188 & 2.92 & 10.85 & 25.94 \\
\hline 0.006 & 0.853 & 45264.663 & 2.83 & 9.25 & 23.50 \\
\hline 0.007 & 0.850 & 45691.899 & 2.75 & 8.09 & 21.44 \\
\hline 0.008 & 0.848 & 46103.282 & 2.67 & 7.20 & 19.67 \\
\hline 0.009 & 0.845 & 46499.975 & 2.60 & 6.50 & 18.14 \\
\hline 0.010 & 0.842 & 46882.984 & 2.53 & 5.93 & 16.80 \\
\hline 0.020 & 0.820 & 50118.240 & 2.01 & 3.24 & 9.16 \\
\hline 0.030 & 0.802 & 52592.822 & 1.66 & 2.27 & 5.95 \\
\hline 0.030 & 0.802 & 52592.822 & 1.66 & 2.27 & 5.95 \\
\hline 0.040 & 0.786 & 54577.859 & 1.41 & 1.77 & 4.36 \\
\hline 0.050 & 0.773 & 56224.148 & 1.22 & 1.46 & 3.55 \\
\hline 0.060 & 0.762 & 57624.371 & 1.07 & 1.25 & 2.98 \\
\hline 0.070 & 0.752 & 58839.270 & 0.96 & 1.09 & 2.56 \\
\hline 0.080 & 0.743 & 59910.566 & 0.87 & 0.98 & 2.31 \\
\hline 0.090 & 0.734 & 60867.974 & 0.79 & 0.88 & 2.14 \\
\hline & & & & & \\
\hline
\end{tabular}

\begin{tabular}{llllll}
\hline 0.100 & 0.727 & 61733.288 & 0.73 & 0.81 & 1.99 \\
\hline 0.200 & 0.672 & 67641.164 & 0.43 & 0.44 & 1.11 \\
\hline 0.300 & 0.635 & 71359.336 & 0.33 & 0.31 & 0.72 \\
\hline 0.400 & 0.605 & 74190.685 & 0.27 & 0.24 & 0.58 \\
\hline 0.500 & 0.580 & 76525.698 & 0.24 & 0.19 & 0.47 \\
\hline 0.600 & 0.558 & 78532.223 & 0.21 & 0.16 & 0.40 \\
\hline 0.700 & 0.537 & 80298.979 & 0.19 & 0.14 & 0.34 \\
\hline 0.800 & 0.519 & 81879.624 & 0.18 & 0.12 & 0.31 \\
\hline 0.900 & 0.502 & 83309.774 & 0.16 & 0.10 & 0.27 \\
\hline 1.000 & 0.486 & 84614.706 & 0.15 & 0.09 & 0.25 \\
\hline
\end{tabular}

$\mathrm{k}$ değerinin 0 olması durumunda EKK için katsayı tahminleri elde edilmektedir. Çizelge 7'ye göre $k=0$ için $\mathrm{R}^{2}$ belirtme katsayısı \%87.44 olmasına rağmen, maksimum VIF değerinin 10'un üzerinde olması (72429682.61) ç̧oklu bağlantının varlığını göstermektedir. Fakat $\mathrm{k}=0.03$ Ridge parametresinde $\mathrm{R}^{2}=\% 80.16$ 'ya düşse de, VIF değeri $10^{\prime}$ un altında olduğundan daha güvenilir sonuçlar elde etmek mümkündür. Arsa vasıflı taşınmazların $\mathrm{k}$ değeri seçiminde olduğu gibi, $k=0.02$ değerinde VIF değeri 10 'a çok yakın olduğundan güvenilir sonuçlar elde edilemeyeceği düşünüldüğünden $k$ değeri 0.03 olarak belirlenmiştir. Uygun $k$ sabitinin belirlenmesinde Çizelge 7 göz önünde bulundurularak $\mathrm{k}$ değeri 0,03 olarak belirlenmiştir. Ridge parametresi olarak seçilen $\mathrm{k}=0.03$ değeri için elde edilen Ridge regresyon analizi sonuçları Çizelge 8 'de sunulmuştur. Ridge regresyon analizi sonucunda VIF değerlerinin $10^{\prime}$ dan küçük olduğu görülmektedir.

Çizelge 8: Konut modeli için Ridge regresyon analiz sonuçları $(k=0.03)$

\begin{tabular}{llllll}
\hline $\begin{array}{c}\text { Bağımsı } \\
\mathbf{z} \\
\begin{array}{c}\text { Değişke } \\
\text { nler }\end{array}\end{array}$ & $\begin{array}{c}\text { Regresyon } \\
\text { Katsayısı }\end{array}$ & $\begin{array}{c}\text { Standart } \\
\text { Hata }\end{array}$ & $\begin{array}{c}\text { Standart- } \\
\text { laştırılmış } \\
\text { Regresyon } \\
\text { Katsayısı }\end{array}$ & VIF & $\begin{array}{l}\text { t } \\
\text { değeri }\end{array}$ \\
\hline $\begin{array}{l}\text { Intercep } \\
\mathrm{t}\end{array}$ & 18709.780 & & & & \\
\hline $\begin{array}{l}\text { Cadde_ } \\
\text { Sokak }\end{array}$ & 4193.0220 & 12325.85 & 0.0089 & 1.1290 & 0.340181 \\
\hline Alan & 182.8194 & 29.88447 & 0.3573 & 5.5887 & 6.117539 \\
\hline $\begin{array}{l}\text { Mulkiye } \\
\text { tD }\end{array}$ & 9285.1860 & 10831.07 & 0.0402 & 3.5978 & 0.857273 \\
\hline Anaokul & 65.7610 & 78.4549 & 0.0430 & 4.3121 & 0.838202 \\
\hline Ilkokul & -24.7603 & 85.49011 & -0.0091 & 1.6083 & -0.28963 \\
\hline Ortaoku & 16.9343 & 21.83446 & 0.0117 & 0.3749 & 0.775576 \\
I & & & & & \\
\hline Lise & -19.2529 & 74.6349 & -0.0093 & 2.1314 & -0.25796 \\
\hline DHastane & 13.9392 & 8.563087 & 0.0239 & 0.3539 & 1.627824 \\
\hline SagOcak & -10.1891 & 28,71941 & -0.0110 & 1.5778 & -0.35478 \\
\hline & & & & & \\
\hline
\end{tabular}




\begin{tabular}{|c|c|c|c|c|c|c|}
\hline Park & 24.6138 & 34.15819 & 0.0236 & 1.7649 & 0.720584 & elde edilmiştir. Model aracılığıyla ulaşılan taşınmaz \\
\hline OyunPark & 5.5818 & 255.1551 & 0.0008 & 2.4617 & 0.021876 & değeri ile gayrimenkul değerleme şirketi tarafından \\
\hline SemtPark & 14.1309 & 8.718002 & 0.0241 & 0.3636 & 1.620889 & akdir edilen taşınmaz değeri de Çizelge $10^{\prime}$ da yer \\
\hline Cami & 55.0954 & 213.682 & 0.0130 & 4.1573 & 0.257838 & ıaktadır. Bu değerler kullanılarak yüzde olarak \\
\hline Karakol & -13.0260 & 68.81046 & -0.0048 & 1.0681 & -0.1893 & $\begin{array}{l}\text {-deger tarkına ulaşılmıştır. Konut } 5 \text { in deger tarkının } \\
\text { fazla olması brüt kullanım alanının diğer seçilen }\end{array}$ \\
\hline Smerkez & 13.0944 & 8.096102 & 0,0226 & 0.3185 & 1.617373 & konutlara göre fazla olmasından ve konutun cephe \\
\hline OtobusD & -46.2459 & 111.5291 & -0.0215 & 4.3883 & -0.41465 & sayısının diğerlerinden farklı olmasından \\
\hline Avm & 10.2486 & 8.412912 & 0.0156 & 0.2676 & 1.218205 & kaynaklanmaktadır. Ayrıca tüm konut vasıflı \\
\hline YapıCins & 7956.0840 & 14255.06 & 0.0337 & 5.9668 & 0.558124 & taşınmazlar dikkate alındığında model sonucu oluşan \\
\hline Bkatı & $\begin{array}{l}- \\
8247.2340\end{array}$ & 6057.141 & -0.0449 & 1.7810 & -1.36157 & $\begin{array}{l}\text { değer ile gayrimenkul şirketi tarafından belirlenen } \\
\text { değer arasındaki fark minimum } \% 0.74 \text {, maksimum }\end{array}$ \\
\hline OdaSayı & $\begin{array}{l}83680.890 \\
0\end{array}$ & 11201.87 & 0.3653 & 3.9175 & 7.470261 & \%44.72 olarak bulunmuştur. \\
\hline Cephe & 4110.8960 & 4783.747 & 0.0218 & 1.0535 & 0.859346 & \\
\hline Bkalan & - & 311.1953 & -1.18 & 4.12 & -23.52 & yer alan değişkenlerin sayısal \\
\hline
\end{tabular}

7319.0800 değerleri ve değer sonucu

Regresyon katsayılarının kullanılması sonucu oluşan regresyon denklemi aşağıdaki gibidir:

Değer $=18709.7800+4193.0220 *$ Cadde_Sokak +1 82.8194*Alan+9285.1860*MulkiyetD+65.7610* Anaokul-24.7603*Ilkokul+16.9343*Ortaokul$19.2528^{*}$ Lise $+13.9392 *$ Dhastane-

10.1891*SagOcak+24.6138*Park $+5.5818^{*}$ OyunP ark+14.1309*SemtPark+55.0954*Cami-

13.0260*Karakol+13.0944*Smerkez-

46.2459*OtobusD+10.2486*Avm $+7956.0840 * Y a$ pıCins-8247.2340*Bkatı+83680.8900*OdaSayı $+4110.8960 *$ Cephe-7318.7040*Bkalan

Illkokula olan mesafe, liseye mesafe, sağlık ocağına olan mesafe, karakola olan mesafe, otobüs durağına olan mesafe, bulunduğu kat ve konut brüt kullanım alanı değişkenleri ile değer arasında zıt yönlü bir ilişki söz konusudur. Cadde-sokak, arsa alanı, mülkiyet durumu, ortaokula olan mesafe, devlet hastanesine olan mesafe, parka olan mesafe, semt parkına olan mesafe, camiye olan mesafe, şehir merkezine olan uzaklık, AVM'ye olan mesafe, yapı cinsi, oda sayısı ve cephe sayısı değişkenlerinin ise modele etkisi pozitif yönlüdür. $t$ değeri göz önünde bulundurulduğunda arsa alanı, şehir merkezine uzaklık, oda sayısı ve konut brüt kullanım alanı değişkenlerinin modeli daha fazla etkilediği görülmektedir.

Kentsel dönüşüm alanında bulunan rastgele seçilen 5 adet konut vasıflı taşınmazın değeri, Çizelge 9'da yer alan değerlerin formülde yerine yazııması sonucunda

\begin{tabular}{|c|c|c|c|c|c|}
\hline & Konut 1 & Konut 2 & Konut 3 & Konut 4 & Konut 5 \\
\hline Cadde/sok & 0 & 0 & 0 & 0 & 0 \\
\hline Alan & 300 & 300 & 300 & 310 & 310 \\
\hline MulkiyetD & 1 & 1 & 1 & 1 & 1 \\
\hline Anaokul & 1515.48 & 1507.48 & 1505.19 & 1502.82 & 1502.82 \\
\hline Ilkokul & 994.324 & 985.793 & 985.714 & 985.222 & 985.222 \\
\hline Ortaokul & 1862.42 & 1854.22 & 1851.73 & 1849.17 & 1849.17 \\
\hline Lise & 1942.61 & 1934.27 & 1940.58 & 1945.55 & 1945.55 \\
\hline DHastane & 6017.02 & 6007.33 & 5991.96 & 5978.51 & 5978.51 \\
\hline SagOcak & 1308.53 & 1301.45 & 1297.21 & 1293.33 & 1293.33 \\
\hline Park & 599.279 & 591.177 & 577.282 & 565.359 & 565.359 \\
\hline OyunPark & 1729.51 & 1731.62 & 1724.89 & 1719.76 & 1719.76 \\
\hline SemtPark & 3077.80 & 3068.89 & 3052.97 & 3039.11 & 3039.11 \\
\hline Cami & 739.593 & 735.120 & 731.342 & 728.107 & 728.107 \\
\hline Karakol & 2166.91 & 2159.99 & 2163.38 & 2165.78 & 2165.78 \\
\hline Smerkez & 5329.19 & 5317.87 & 5303.89 & 5291.50 & 5291.50 \\
\hline OtobusD & 514.936 & 516.671 & 500.869 & 488.088 & 488.088 \\
\hline Avm & 1405.80 & 1392.79 & 1382.03 & 1372.30 & 1372.30 \\
\hline YapıCins & 0 & 0 & 0 & 0 & 0 \\
\hline Bkatı & 0 & 0 & 0 & 0 & 1 \\
\hline OdaSayı & 3 & 3 & 3 & 3 & 4 \\
\hline Cephe & 2 & 2 & 1 & 1 & 1 \\
\hline Bkalan & 43.54 & 44.12 & 43.74 & 44.17 & 88.34 \\
\hline $\begin{array}{l}\text { Değer } \\
\text { (Model) }\end{array}$ & 303.961 & 298.528 & 296.296 & 294.148 & 463.149 \\
\hline
\end{tabular}


Çizelge 10. Konut modeli sonucu elde edilen değer ile gayrimenkul şirketi tarafından belirlenen değer karşılaştırması

\begin{tabular}{|c|c|c|c|c|c|}
\hline & $\begin{array}{l}\text { Konut } \\
1\end{array}$ & $\begin{array}{l}\text { Konut } \\
2\end{array}$ & $\begin{array}{l}\text { Konut } \\
3\end{array}$ & $\begin{array}{l}\text { Konut } \\
4\end{array}$ & $\begin{array}{l}\text { Konut } \\
5\end{array}$ \\
\hline $\begin{array}{l}\text { Değer (Model) } \\
\text { (TL) }\end{array}$ & 303.96 & 298.52 & 296.29 & 294.14 & 463.14 \\
\hline $\begin{array}{l}\text { Değer } \\
\text { (Değerleme } \\
\text { Şirketi)(TL) }\end{array}$ & 301.71 & 301.34 & 302.74 & 318.47 & 320.01 \\
\hline Fark (\%) & 0.74 & 0.93 & 2.13 & 7.64 & 44.72 \\
\hline
\end{tabular}

Çizelge $11^{\prime}$ de tüm arsa ve konut vasıflı taşınmazlara ait minimum model değeri, maksimum model değeri, gayrimenkul şirketi tarafından belirlenen minimum değer, gayrimenkul şirketi tarafından belirlenen maksimum değer, ortalama fark gösterilmiştir. Model sonucu elde edilen değerler arasındaki minimum maksimum değer arası fark gayrimenkul şirketi tarafından belirlenen maksimum ve minimum değer arası farktan azdır. Bu durumun model sonucu elde edilen değerlerin birbirine yakın ve tutarlı değerler olmasından kaynaklandığı yorumu yapılmaktadır. Gayrimenkul şirketi tarafından bulunan değer farklarının fazla olması ise değerin sübjektif olarak belirlenmesi kaynaklı olduğu çıkarımı yapılmaktadır.

Çizelge 11. Arsa ve konut vasıflı tüm taşınmazların model değeri ve gayrimenkul şirketi tarafından bulunan değer ile karşılaştırması

\begin{tabular}{lll}
\hline \multicolumn{1}{c}{ Taşınmazın Vasfı } & Arsa & Konut \\
\hline $\begin{array}{l}\text { Min.Değer } \\
\text { (Model) (TL) }\end{array}$ & 325.56 & 303.96 \\
\hline $\begin{array}{l}\text { Maks.Değer } \\
\text { (Model) (TL) }\end{array}$ & 546,45 & 463.14 \\
\hline $\begin{array}{l}\text { Min.Değer } \\
\text { (Değerleme Şirketi) (TL) }\end{array}$ & 367.50 & 301.71 \\
\hline $\begin{array}{l}\text { Maks.Değer } \\
\text { (Değerleme Şirketi) (TL) }\end{array}$ & 858.50 & 320.01 \\
\hline Ortalama Fark (TL) & 151.05 & 193.47 \\
\hline
\end{tabular}

\section{Tartışma ve Sonuç}

Türkiye'de taşınmaz değerlemesi; kamulaştırma, vergilendirme, arazi toplulaştırması, kentsel dönüşüm gibi birçok yasal uygulama içerisinde yer almaktadır. Bu nedenle çok sayıda yasal altlığa sahiptir. Benzer nitelikli taşınmazların değeri tek bir yöntem ile değil, farklı değerleme uzmanları tarafından belirlenen farklı yöntemler ile gerçekleştirilmektedir. Bunun nedeni, ülkemizde çok sayıda taşınmazın aynı anda değerlemesine olanak sağlayan kitlesel değerleme standardının bulunmamasıdır.

Benzer niteliğe sahip taşınmazların değerlemesi belli standart ve model aracılığıyla gerçekleştirilememesi nedeniyle rant kontrolü sağlanamamaktadır. Bu da kentsel dönüşüm uygulamalarında vatandaşın bakış açısını etkilemektedir ve kişiler arasındaki uzlaşma süresini arttırmaktadır. Ayrıca taşınmaza gereğinden az ya da fazla değer biçilmesine neden olmaktadır.

$\mathrm{Bu}$ çalışma ile kentsel dönüşüm alanlarında taşınmazın değerinde etkili olan faktörlerin de göz önünde bulundurulduğu bir model aracılığıyla aynı anda benzer nitelikli birçok taşınmazın değerinin saptanabileceği ortaya konulmuştur. Böylece daha az sürede ve daha az maliyetle taşınmazın değerine ulaşmak mümkün olmaktadır. Ayrıca kitlesel değerleme yöntemi, taşınmaz değerlemesinde istatistiksel yöntemlerin kullanılması ile değerleme uzmanına dayanan tahminlerin dışında analizi ve güncellenmesi yapılabilen taşınmaz değeri kestirimini mümkün kılmaktadır.

Elâzığ ili Merkez ilçesi Cumhuriyet Mahallesinde bulunan 21.69 hektarlık kentsel dönüşüm alanındaki arsa ve konut vasıflı taşınmazlara Ridge regresyon analizi kullanılarak kitlesel değerleme yöntemi uygulanmıştır. 51 adet arsa, 348 adet konut vasıflı taşınmaza ait veriler analize uygun hale getirilip temel istatistik sonuçları incelendiğinde değişkenler arasında yüksek korelasyon var olduğu görülmüştür. Yüksek korelasyon değişkenler arasında çoklu bağlantı sorununun olabileceğini göstermektedir. Çoklu bağlantı sorununun varlığı değişkenler arasındaki yüksek korelasyonun dışında, VIF değerinin incelenmesiyle kesinlik kazanmıştır. Bu sorun çözülmeden gerçekleştirilen analiz ile anlamlı sonuçlar elde etmek mümkün değildir. Sorunu çözmek için analize veri eklenmesi, yüksek korelasyonlu verilerin analizden çıkarılması veya yanlı tahmin yöntemlerinin uygulanması gerekmektedir. Analizde kullanılacak veri sayısının arttırılması çalışma alanının tanımlı olması sebebiyle mümkün olmamaktadır. Veri çıkartılması da analiz sonucu oluşacak modelde etkili olacak faktör sayısını olumsuz yönde etkilemektedir. Bu nedenle yanlı bir tahmin yöntemi olan Ridge regresyon analizinin kullanılarak arsa modeli ve konut modeli oluşturulmuştur.

Arsa modeli ile elde edilen başarı oranı $k=0$ olduğu durumda \%90.7 iken k=0.03 olduğu yanlı tahmin sonucunda \%71.56 olmuştur. Konut modeliyle ile elde edilen başarı oranı $\mathrm{k}=0$ durumunda \%87.44 iken $\mathrm{k}=0.03$ olduğunda ise $\% 80.16$ olmuştur. Başarı oranının düşmesi istenilen bir durum değildir. Fakat 
bu oranın düşüşü, çoklu bağlantı sorununun varlığını ve Ridge regresyon uygulanarak giderildiğini göstermektedir. Çoklu bağlantı sorunu giderilerek, tahminlerin gerçek değerine yaklaşması sağlanmıştır. Analiz sonrası elde edilen model üzerde değişkenlerin değeri yerine yazılarak, değer bilgisine ulaşılmıştır. Model sonrası ulaşılan değer ile daha önce gayrimenkul şirketi tarafından belirlenen değer karşılaştırılarak, yüzde olarak farkları incelenmiştir.

Gayrimenkul şirketi tarafından yapılan değer takdirinde, arsanın değeri emsal yöntemi ile konutların değeri ise maliyet yöntemi ile belirlenerek bu iki değer toplanmıştır. Model sonucu elde edilen değere ise alanda bulunan tüm taşınmazların benzer nitelikte olduğu göz önünde bulundurularak ve taşınmazların vasfına uygun olarak değerinde etkili olan faktörlerinde dikkate alınması sonucunda ulaşılmıştır. Değer takdirinde kullanılan yöntemlerin farklılık göstermesinden dolayı model sonucu elde edilen değer ile gayrimenkul şirketi tarafından belirlenen değer arasında farklılıklar görülmektedir. Taşınmaz değerlemeye; vergilendirme, kamulaştırma, devletleştirme, özelleştirme, toprak düzenlemeleri, tescile esas işlemler, irtifak hakkı tesisi gibi kamusal uygulamalar ile sermaye piyasası, bankacılık, kredilendirme, sigortacılık gibi özel sektör uygulamalarında da yoğun bir şekilde ihtiyaç duyulmasından ötürü bu farklılıklar önem taşımaktadır. Ekonominin yanı sıra, kırsal ve kentsel toprak düzenlemeleri, kentsel dönüşüm ve kamulaştırmalar açısından önem taşıyan taşınmaz değerlemenin şeffaflı̆ı̆ın sağlanabilmesi için ülkelerin sağlıklı işleyen değerleme sistemlerinin olması gerekmektedir(Erdem, 2018).

\section{Kaynaklar}

Açlar, A., 1977. Kentsel Alanlarda Taşınmaz Değerlerinin Saptanması ve Stokastik Yöntemlerin Uygulanmasına Iliş̧in Bir Araştırma, Doçentlik Tezi, IDMMAM Yayını, İstanbul.

Akçay, A., Sarıözkan, S., 2015. Yumurta Tavukçuluğunda Gelirin Ridge Regresyon Analiziyle Tahmini, Ankara Üniversitesi Veterinerlik Fakültesi Dergisi, 62,69-74.

Anonim, 2006. Uluslararası Değerleme Standartları (Türkçe), Sermaye Piyasasında Uluslararası Değerleme Standartları Hakkında Tebliğ, Seri: VIII, No: 45, Ankara.
Çakır, P.,2013. Arsa Vasıflı Taşınmazların Değerine Etki Eden Faktörlerin ve Bu Faktörlerin Önem Sıralarının Belirlenmesi, Yüksek Lisans Tezi, Ondokuz Mayıs Üniversitesi Fen Bilimleri Enstitüsü Harita Mühendisliği Anabilim Dalı, Samsun, 113.

Erdem N. 2017. Toplu (Küme) Değerleme Uygulama Örnekleri Ve Ülkemiz İçin Öneriler, 16. Türkiye Harita Bilimsel ve Teknik Kurultayı, 3-6 Mayıs, Ankara.

Erdem, N., 2018. Türkiye Taşınmaz Değerleme Sisteminin Yeniden Yapılandırıımasına Yönelik Bilimsel Çalışma ve Öneriler Üzerine Bir Değerlendirme. Ömer Halisdemir Üniversitesi Mühendislik Bilimleri Dergisi,7, 159-170.

Güngör, E., 1999. Gayrimenkul Değerlemesi ve Türkiye'de Sermaye Piyasalarında Gayrimenkul Ekspertiz Şirketlerine Yönelik Düzenlemeler Yapılmasına İlişkin Öneriler, Yeterlik Etüdü, T.C. Başbakanlık Sermaye Piyasası Kurulu Kurumsal Yatırımcılar Dairesi, Ankara.

Hoerl, A.E. \& Kennard, R.W.,1970. Ridge regression: biase destimation for non-orthogonal problems. Technometrrics, 12,55-67.

Köktürk, E. ve Köktürk, E. 2016, Taşınmaz Değerlemesi ,Üçüncü Baskı, SEÇKiN Yayınevi, Türkiye.

Marquardt, D.W \& Snee, R.D., 1975. Ridge Regression in Pratice. The American Statistician, February, Vol. 29, 3-20.

Maxwell, S.E., 2000. Sample Size and Multiple Regression Analysis. Psychological Methods, 5, 434-458.

Özcan, A., 2003. Farklı Sosyo-Ekonomik ve Kültürel Grupların Etkileşimi (Elazığ Cumhuriyet Mahallesi Örneği), Yüksek Lisans Tezi, Fırat Üniversitesi Sosyal Bilimler Enstitüsü, Sosyoloji Anabilim Dalı, Elazığ, 111.

Tanrıvermiş, H. 2017. Gayrimenkul Değerleme Esasları Lisanslama Sınavları Çalışma Kitabı., Ankara, 251.

TKGM, 2014. Tapu ve Kadastro Modernizasyon Projesi Tarafından Pilot Uygulama Raporu, Eylül, Ankara.

Tokat, A., 2014. Taşınmaz Bilimlerinde Kitlesel Değerleme İşlemleri ve Uygulamaları. Doktora Semineri (Basılmamış), Ankara Üniversitesi Fen Bilimleri Enstitüsü Taşınmaz Geliştirme Anabilim Dalı, Ankara, 100.

Yahşi, E.,2007. Konut Değerlemesi ve Konut Değerlerini Etkileyen Faktörlerin Regresyon Analizi ile İncelenmesi, Yüksek Lisans Tezi, İstanbul Teknik Üniversitesi Fen Bilimleri Enstitüsü Disiplinler Arası Anabilim Dalı, İstanbul, 145. 
Yıldız, Ü., 2014. Gayrimenkul Birimlerinde Kitlesel Değerleme Uygulamaları ve Türkiye İçin Model Önerisi, Yüksek Lisans Tezi, Ankara Üniversitesi Fen Bilimleri Enstitüsü, Ankara 227.

Yılmaz, A., 2010. Çok Ölçütlü Karar Destek Sistemleri ile Taşınmaz Değerleme ve Oran Çalışması, Yüksek Lisans Tezi, Yıldız Teknik Üniversitesi Fen Bilimleri Enstitüsü Harita Mühendisliği Anabilim Dalı, İstanbul, 194.

\section{internet kaynakları}

1-International Association of Assessing Officers. http://www.iaao.org/media/standards/MARP_2018.pdf. (Erişim Tarihi: Mart 2018).

2- https://www.elazig.bel.tr/icerik.php?id=217

(15.09.2017)

3-https://vimeo.com/119234913 (08.02.2018) 